\title{
Induction of puberty with human chorionic gonadotropin (hCG) followed by reversal of hypogonadotropic hypogonadism in Kallmann syndrome
}

\author{
Malgorzata M. Pierzchlewska', Maciej G. Robaczyk', Ida Vogel ${ }^{2}$ \\ ${ }^{1}$ Department of Endocrinology, Aalborg University Hospital, Aalborg, Denmark \\ ${ }^{2}$ Department of Clinical Genetics, Aarhus University Hospital, Aarhus, Denmark
}

\begin{abstract}
Introduction: Kallmann syndrome (KS) is a rare congenital disorder combining hypogonadotropic hypogonadism (HH) due to GnRH-deficiency with anosmia. Traditionally thought to require lifelong therapy, it has transpired to be a reversible condition in some patients. Material and methods: We present a case of a 22-year-old man with absent puberty due to KS, in whom genetic testing revealed heterozygosity for a mutation in the PROK2 gene. Pubertal development and virilisation was achieved by using human chorionic gonadotropin (hCG) injections followed by testosterone replacement. During the follow-up, we observed reversal of hypogonadism allowing discontinuation of testosterone treatment. Normalisation of testicular volume as well as gonadotropin and inhibin B levels through a two-year post-reversal period was seen.

Conclusions: Treatment with hCG is effective in inducing pubertal development and may have advantage over testosterone replacement due to potential gonadal maturation. Regular assessment of testicular volume and biochemical surveillance including measuring of serum inhibin B and gonadotropins are necessary for timely detection of reversal of GnRH deficiency. (Endokrynol Pol 2017; 68 (6): 692-696)
\end{abstract}

Key words: Kallmann syndrome, hCG treatment, reversal of hypogonadotropic hypogonadism

\section{Streszczenie}

Wstęp: Zespół Kallmanna jest rzadkim, wrodzonym zaburzeniem łączącym hipogonadyzm hipogonadotropowy spowodowany niedoborem GnRH z anosmią. Tradycyjnie uważany za wymagający leczenia przez całe życie u części pacjentów okazuje się stanem odwracalnym. Opis przypadku: Prezentujemy przypadek 22-letniego mężczyzny z brakiem cech pokwitania z powodu zespołu Kallmanna, u którego badanie genetyczne ujawniło heterozygotyczność dla mutacji genu PROK2. Rozwój cech pokwitania i wirylizacji osiągnięto, podając iniekcje ludzkiej gonadotropiny kosmówkowej (hCG), a stosując następnie leczenie testosteronem. Podczas obserwacji wystąpiło zjawisko samoistnego ustąpienia hipogonadyzmu hipogonadotropowego (tzw. reversal), co pozwoliło na przerwanie leczenia testosteronem. W ciągu następnych 2 lat stwierdzono normalizację wielkości jąder, a także stężeń gonadotropin i inhibiny B.

Wnioski: Leczenie hCG jest skuteczne w indukcji pokwitania i może mieć przewagę nad leczeniem testosteronem z uwagi na możliwość procesu dojrzewania jąder. Częsta ocena wielkości jąder i kontrola parametrów biochemicznych, takich jak stężenie gonadotropin i inhibiny B, są konieczne dla wczesnego wykrycia zjawiska reversal. (Endokrynol Pol 2017; 68 (6): 692-696)

Słowa kluczowe: zespół Kallmana, leczenie hCG, samoistne ustąpienie hipogonadyzmu hipogonadotropowego

\section{Introduction}

Kallmann syndrome (KS) is a rare congenital form of idiopathic hypogonadotropic hypogonadism $(\mathrm{HH})$ in which gonadotropin-releasing hormone $(\mathrm{GnRH})$ deficiency is associated with smell sense disorders due to hypoplasia or aplasia of the olfactory bulbs. KS is a clinically and genetically heterogeneous disease with a variable degree of hypogonadism and associated non-reproductive abnormalities as well as a complex genetic transmission. Typically, a lifelong therapy is required, but some patients exhibit spontaneous recovery of reproductive endocrine function, i.e. reversal $[1,2]$.

\section{Case report}

A 22-year-old man, with previous unremarkable medical history, was referred to our centre due to absence of puberty. Over the preceding few years, the patient had become aware of the inadequacy of his physical development, concerning voice change, development of facial hair, and genital size. He self-reported anosmia. His older brother and younger sister underwent normal puberty. 
Table I. Initial hormonal measurements

Tabela I. Pomiary poziomu hormonów

\begin{tabular}{lll}
\hline Hormone & Value & Reference \\
\hline Total testosterone & $0.65 \mathrm{nmol} / \mathrm{L}$ & $10.3-27.4$ \\
\hline $\begin{array}{l}\text { Sex hormone binding globulin } \\
\text { (SHBG) }\end{array}$ & $52 \mathrm{nmol} / \mathrm{L}$ & $24-77$ \\
\hline Androstenedione & $2.72 \mathrm{nmol} / \mathrm{L}$ & $1.7-6.9$ \\
\hline $\begin{array}{l}\text { Dehydroepiandrosterone sulphate } \\
\text { (DHEA-S) }\end{array}$ & $7920 \mathrm{nmol} / \mathrm{L}$ & $3000-12000$ \\
\hline 17-hydroxy-progesterone & $2.24 \mathrm{nmol} / \mathrm{L}$ & $<8$ \\
\hline Luteinising hormone (LH) & $1.4 \mathrm{IU} / \mathrm{L}$ & $1.7-8.6$ \\
\hline Follicle-stimulating hormone (FSH) & $2.0 \mathrm{IU} / \mathrm{L}$ & $1.5-12.4$ \\
\hline Inhibin B & $52 \mathrm{pg} / \mathrm{mL}$ & $55-300$ \\
\hline Thyroid-stimulating hormone (TSH) & $2.6 \mathrm{mlU} / \mathrm{L}$ & $0.3-4.5$ \\
\hline Total Triiodothyronine (T3) & $1.9 \mathrm{nmol} / \mathrm{L}$ & $1.1-2.5$ \\
\hline Total Thyroxine (T4) & $126 \mathrm{nmol} / \mathrm{L}$ & $60-140$ \\
\hline Cortisol & $490 \mathrm{nmo} / \mathrm{L}$ & $200-600$ \\
\hline Adrenocorticotropic hormone & $70 \mathrm{ng} / \mathrm{mL}$ & $10-60$ \\
(ACTH) & & \\
\hline Insulin-like growth factor-1 & $42 \mathrm{nmol} / \mathrm{L}$ & $10-45$ \\
(IGF-1) & & \\
\hline Insulin-like growth factor-binding \\
protein 3 (IGF-BP3) & $6030 \mathrm{ng} / \mathrm{mL}$ & SDS 1.53 \\
\hline Prolactin & $73.5 \mathrm{mlU} / \mathrm{L}$ & $70-450$ \\
\hline
\end{tabular}

At physical examination he had height of $1.82 \mathrm{~m}$, weight of $80.3 \mathrm{~kg}$, and no clear eunuchoidal proportions. He had a light voice and no facial hair growth but there were signs of normal adrenarche, i.e. sparse pubic and axillary hair growth. Pubic hair and phallic development were Tanner stage II. Both testes were prepubertal and found in the scrotum. Left and right testicular volume by ultrasound was $2.8 \mathrm{ml}$ and $1.9 \mathrm{ml}$, respectively. No gynecomastia, hearing impairment, visual field defects or impaired visual acuity, bimanual synkinesia, midline defects, or skeletal abnormalities were observed.

Bone age determined by radiographs was 17.5-18 years. Bone densitometry (DEXA, Hologic) showed $\mathrm{Z}$ score of -1.8 and -0.2 at the lumbar spine and total hip, respectively. Abdominal ultrasound was normal. MRI showed pituitary gland of a normal size and appearance. Poorly developed olfactory sulci and absent/ /hypoplastic olfactory bulbs were noticed.

Basal hormonal evaluation revealed very low testosterone level, low normal range LH and FSH levels, low inhibin B. Other hormonal measurements, including hypophyseal hormones, were normal (Table I). A normal 46,XY karyotype was found.

Genetic testing was performed by PCR and nextgeneration sequencing by Centogene $\mathrm{AB}$, Rostock,

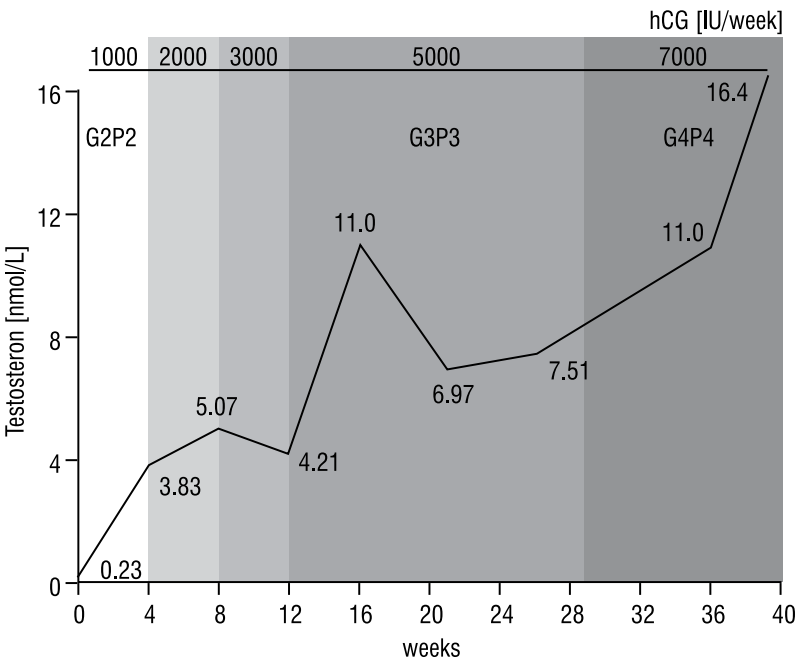

Figure 1. Testosterone levels and Tanner staging during $h C G$ -treatment

Rycina 1. Poziomy testosteronu i ocena w skali Tannera podczas leczenia $h C G$

Germany. The KS/HH NGS panel included 14 different genes (ANOS1, CHD7, FGF8, FGFR1, GNRH1, GRNHR, HESX1, KISS1, KISS1R, PROK2, PROKR2, SEMA3A, TAC3, TACR3). A single base pair deletion in exon 2 of the PROK2 gene (c.163delA p.155) was identified in the proband. Segregation analyses showed that the variant was inherited from the unaffected father. A detailed family anamnesis did not reveal other symptomatic family members.

Treatment with hCG (Pregnyl $^{\circledR}$ ) was started with a weekly dose of 1000 IU s.c., administered as 500 IU twice weekly, gradually increased up to 7000 IU per week, resulting in a gradual increase of testosterone level as well as pubertal development (Figure 1). After 40 weeks of hCG treatment a satisfactory effect on virilisation and a $44 \%$ increase in combined testicular volume were achieved. Pubic hair and phallic development achieved Tanner stage IV. Left and right testicular volume by ultrasound was $3.6 \mathrm{ml}$ and $4.8 \mathrm{ml}$, respectively. Sparse facial hair growth, facial acne, deepening of the voice and increased lean body mass became clearly manifest. Due to a prompt fall in testosterone level to the baseline value after cessation of hCG treatment, testosterone replacement therapy was initiated after a two-week treatment interruption, using long-acting testosterone undecanoate $\left(\mathrm{Nebido}^{\circledR}\right)$ at a dose of $1000 \mathrm{mg}$ i.m. and injection interval of 15-16 weeks. During testosterone therapy an unexpected increase in inhibin B and gonadotropin levels was observed (Figure 2 and 3), which led to discontinuation of hormonal therapy after 14 months (five injections), considering a likely reversal of hypogonadism. Levels of testosterone and gonadotropins remained normal through a two-year 


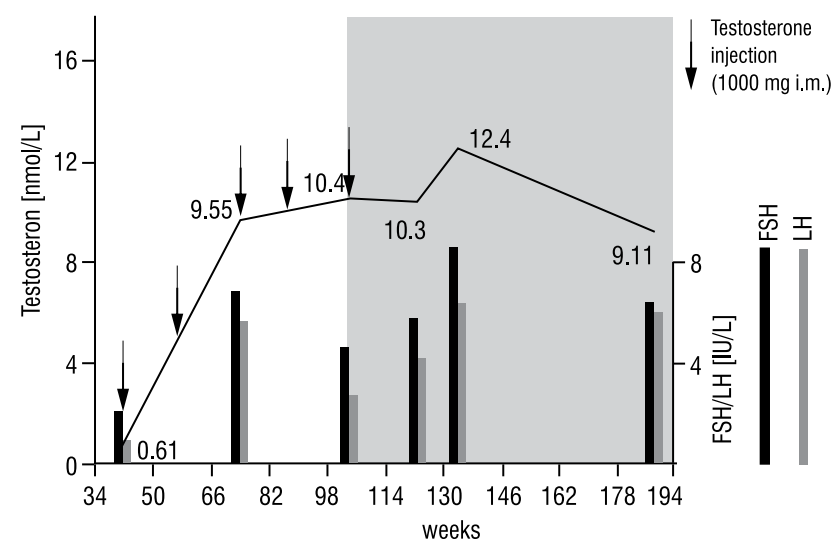

Figure 2. Testosterone, FSH, and LH levels during testosterone therapy and after cessation of treatment

Rycina 2. Poziomy testosteronu, FSH i LH podczas leczenia testosteronem i po jego zaprzestaniu

post-reversal period, and inhibin B continued to increase (Figure 2 and 3). At the end of the follow-up, testicular volume was normal (left and right testicular volume by orchidometer: 17 and $20 \mathrm{ml}$, respectively), development of secondary sexual characteristics was completed, and psychosexual functioning as well as self-confidence improved.

\section{Discussion}

Most patients with KS present as sporadic cases, but a proportion of cases are inherited. The commonest mode of inheritance is $\mathrm{X}$-linked recessive, as seen in affected males with mutations in KAL1 (ANOS1), the first described gene for KS. During the last two decades, however, a substantial number of other genes have been found to cause normosmic $\mathrm{HH}(\mathrm{nHH})$ and $\mathrm{KS}$ also in autosomal dominant and autosomal recessive inheritance patterns, and so the complexity of genetic testing and its prioritising has become a challenge for clinicians. Costa-Barbosa et al. [3] have proven that certain clinical features of KS, such as unilateral renal agenesis, bimanual synkinesia, dental agenesis, and syndactyly, are highly associated with mutations in specific genes. Our patient did not exhibit any of the anomalies that could help with prioritising genetic screening. The pedigree suggested an autosomal recessive mode of inheritance in this family or a de novo mutation in the patient. The only genetic defect we found in this patient was a monoallelic mutation (c.163delA p.155) in the PROK2 gene, coding for prokineticin 2 peptide. The prokineticin 2 signalling pathway plays a critical role in olfactory bulb development and reproductive maturation in mammals. Loss-of-function mutations in the PROK2 and PROKR2 genes, the latter coding for prokineticin receptor, are a newly discovered molecular basis

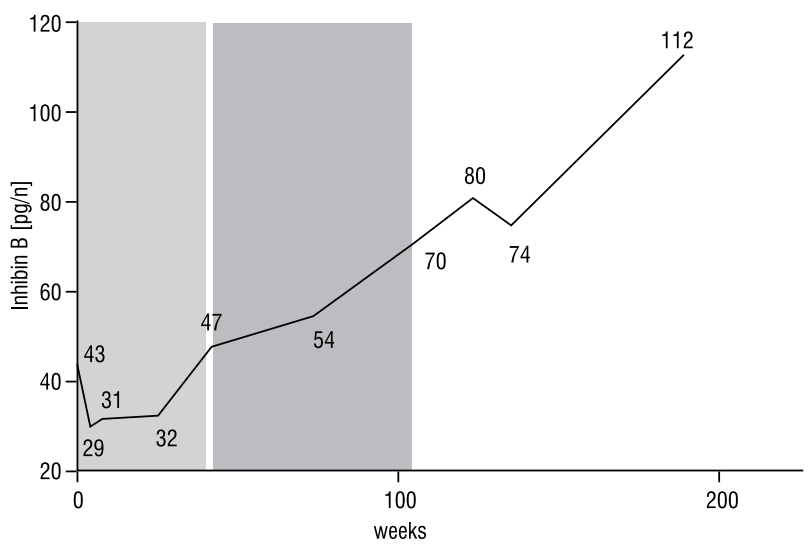

Figure 3. Inhibin B during hCG-treatment, testosterone therapy, and after cessation of treatment

Rycina 3. Poziomy inhibiny B podczas leczenia hCG, testosteronem i po zaprzestaniu leczenia

of autosomal KS [4]. Non-reproductive, non-olfactory anomalies, such as fibrous dysplasia, sleep disorders, synkinesia, and epilepsy [5], are rare and occur mostly in male patients with monoallelic mutations, whereas those with biallelic mutations have severe reproductive changes, such as micropenis and cryptodorchism [6]. Those mutations are predominantly detected in the heterozygous state with incomplete penetrance and variable expressivity. Homozygous and compound heterozygous changes are rare, but they have already been described, for this particular PROK2 mutation by Pitteloud et al. [7]. The authors described KS or $\mathrm{nHH}$ in three siblings who harboured the homozygous deletion. Contrary to our case, normal puberty and fertility was observed in the other two siblings, who were heterozygous for the mutation. However, the spectrum of clinical manifestations in family members with the same monoallelic mutation in the PROK2 and $P R O K R 2$ genes can range greatly from no symptoms, through partial or absent puberty but normal olfaction, anosmia/hyposmia but normal pubertal development, to full-blown KS. Due to this phenotypic heterogeneity, it has been postulated that the heterozygous state for a PROK2/PROKR2 mutation alone is not sufficient to cause $\mathrm{KS}$ or $\mathrm{nHH}$ phenotype, and that monoallelic cases are in fact digenic or oligogenic, in that they also carry additional mutations in other genes known (or currently unknown) to cause GnRH deficiency [8]. Not dismissing this possibility, we suggest that the family might demonstrate incomplete penetrance of the mutation, and factors we do not yet understand permit both the asymptomatic presentation of the father and the full KS spectrum of the son carrying the same monoallelic mutation. The reduced penetrance of the disease could also facilitate the reversal of hypogonadism in this patient. 
The standard management of male adolescents and young adults with $\mathrm{HH}$ is to use testosterone replacement to induce virilisation and psycho-sexual maturation [9]. However, testosterone treatment in those patients will not induce testicular growth or spermatogenesis. Furthermore, Liu et al. [10] have shown that prior testosterone therapy is associated with a slower response to subsequent fertility treatment with gonadotropins, suggesting that the use of testosterone for pubertal induction may have an adverse effect on fertility potential by preventing maturation of testes. The use of gonadotropins as a physiologic stimulus of testes seems to provide some benefit in enhancing testicular growth and inducing spermatogenesis [11]. Therapy with hCG alone, the hormone with a predominant LH-activity, has a marked effect on testosterone levels, regardless of the initial testicular volume, while the effect on testicular growth and sperm production is related to the initial volume of testes [11]. Interestingly, a recent multicentre prospective study [12] has delivered further arguments for early gonadotropin treatment in adolescents with $\mathrm{HH}$. The authors have shown that the combined treatment with hCG and recombinant follicle-stimulating hormone $(\mathrm{rFSH})$ is a safe means of inducing all features of pubertal development, including the acquisition of fertility and a marked improvement of quality of life, regardless of previous testosterone replacement. The plasma half-life of hCG is long enough to allow administration twice a week in the form of subcutaneous injections. It can be self-administered by the patient after a proper instruction. Our patient tolerated the treatment well. We aimed at achieving testosterone levels at the lower end of normal range to induce a more rapid virilisation. Since the primary objective of treatment was to induce virilisation and not fertility, the possibility of adding rFSH to hCG treatment $[12,13]$ was not considered at this stage. The decision to switch over to testosterone replacement in our patient after a 10 -month period of hCG treatment was arbitrary due to lack of evidence to suggest the optimal duration of gonadotropin exposure in this clinical context.

An interesting feature of $\mathrm{KS}$ is a spontaneous activation of the hypothalamic-pituitary-gonadal (HPG) axis, termed reversal, occurring mostly in male patients during early adulthood [1]. Sidhoum et al. [2], assessing of a large cohort of 308 patients, found a lifetime incidence of reversal of GnRH deficiency to be $15-22 \%$. Reversal can occur even in patients with cryptodorchism and micropenis, and no preponderance of a specific genetic spectrum that favours reversal is seen. Furthermore, in a small subset of patients the reversal is not permanent and relapse can occur. Increasing testicular volume under testosterone treatment and a rise in testosterone levels after cessation of testosterone replacement are the typical features of reversal. In our patient, we observed two distinct biochemical changes that raised this suspicion. Firstly, we found an unexpected increase in gonadotropin levels at the time of the third testosterone injection. Secondly, levels of inhibin B, initially suppressed after commencing hCG treatment, began to rise in the last 16 weeks of the hCG period and rose continuously under testosterone treatment, despite cessation of hCG exposure. We suggest that rising levels of gonadotropins and inhibin B may be the early biochemical features of reversal during ongoing testosterone replacement. In the presented case, reversal must have occurred at any time between the first and the third testosterone injection, i.e. over a time span of 30 weeks, suggesting that a closer biochemical surveillance would be more appropriate for early detection of reversal and thus timely discontinuation of testosterone.

\section{Conclusions}

The use of hCG to induce puberty in young male adults with $\mathrm{KS}$ is clinically effective, allows precise titration to achieve adequate testosterone levels, and may have an advantage over testosterone replacement due to potential gonadal maturation. Regular assessment of testicular volume and biochemical surveillance including are crucial for timely detection of reversal of GnRH deficiency.

\section{Disclosure}

The authors have no conflicts of interest to disclosure.

\section{References}

1. Raivio T, Falardeau J, Dwyer A, et al. Reversal of idiopathic hypogonadotropic hypogonadism. N Engl J Med. 2007; 357(9): 863-873, doi: 10.1056/ NEJMoa066494, indexed in Pubmed: 17761590.

2. Sidhoum VF, Chan YM, Lippincott MF, et al. Reversal and relapse of hypogonadotropic hypogonadism: resilience and fragility of the reproductive neuroendocrine system. J Clin Endocrinol Metab. 2014; 99(3): 861-870, doi: 10.1210/jc.2013-2809, indexed in Pubmed: 24423288.

3. Costa-Barbosa FA, Balasubramanian R, Keefe KW, et al. Prioritizing genetic testing in patients with Kallmann syndrome using clinical phenotypes. J Clin Endocrinol Metab. 2013; 98(5): E943-E953, doi: 10.1210/ jc.2012-4116, indexed in Pubmed: 23533228.

4. Dodé C, Teixeira L, Levilliers J, et al. Kallmann syndrome: mutations in the genes encoding prokineticin-2 and prokineticin receptor-2. PLoS Genet. 2006; 2(10): e175, doi: 10.1371/journal.pgen.0020175, indexed in Pubmed: 17054399.

5. Cole LW, Sidis Y, Zhang C, et al. Mutations in prokineticin 2 and prokineticin receptor 2 genes in human gonadotrophin-releasing hormone deficiency: molecular genetics and clinical spectrum. J Clin Endocrinol Metab. 2008; 93(9): 3551-3559, doi: 10.1210/jc.2007-2654, indexed in Pubmed: 18559922.

6. Sarfati J, Dodé C, Young J. Kallmann syndrome caused by mutations in the PROK2 and PROKR2 genes: pathophysiology and genotypephenotype correlations. Front Horm Res. 2010; 39: 121-132, doi: 10.1159/000312698, indexed in Pubmed: 20389090.

7. Pitteloud N, Zhang C, Pignatelli D, et al. Loss-of-function mutation in the prokineticin 2 gene causes Kallmann syndrome and normosmic idiopathic hypogonadotropic hypogonadism. Proc Natl Acad Sci U S A. 2007; 104(44): 17447-17452, doi: 10.1073/pnas.0707173104, indexed in Pubmed: 17959774.

8. Balasubramanian R, Plummer L, Sidis Y, et al. The puzzles of the prokineticin 2 pathway in human reproduction. Mol Cell Endocrinol. 2011; 346(1-2): 44-50, doi: 10.1016/j.mce.2011.05.040, indexed in Pubmed: 21664414. 
9. Boehm U, Bouloux PM, Dattani MT, et al. Expert consensus document: European Consensus Statement on congenital hypogonadotropic hypogonadism--pathogenesis, diagnosis and treatment. Nat Rev Endocrinol. 2015; 11(9): 547-564, doi: 10.1038/nrendo.2015.112, indexed in Pubmed: 26194704.

10. Liu PY, Baker HW, Jayadev V, et al. Induction of spermatogenesis and fertility during gonadotropin treatment of gonadotropin-deficient infertile men: predictors of fertility outcome. J Clin Endocrinol Metab. 2009; 94(3): 801-808, doi: 10.1210/jc.2008-1648, indexed in Pubmed: 19066302.

11. Vicari E, Mongioì A, Calogero AE, et al. Therapy with human chorionic gonadotrophin alone induces spermatogenesis in men with isolated hypogonadotrophic hypogonadism--long-term follow-up. Int J Androl. 1992; 15(4): 320-329, doi: 10.1111/j.1365-2605.1992.tb01131.x, indexed in Pubmed: 1516981.
12. Rohayem J, Hauffa BP, Zacharin M, et al. "German Adolescent Hypogonadotropic Hypogonadism Study Group". Testicular growth and spermatogenesis: new goals for pubertal hormone replacement in boys with hypogonadotropic hypogonadism? -a multicentre prospective study of hCG/rFSH treatment outcomes during adolescence. Clin Endocrinol (Oxf). 2017; 86(1): 75-87, doi: 10.1111/cen.13164, indexed in Pubmed: 27467188

13. Zacharin M, Sabin MA, Nair VV, et al. Addition of recombinan follicle-stimulating hormone to human chorionic gonadotropin treatment in adolescents and young adults with hypogonadotropic hypogonadism promotes normal testicular growth and may promote early spermatogenesis. Fertil Steril. 2012; 98(4): 836-842, doi: 10.1016/j. fertnstert.2012.06.022, indexed in Pubmed: 22763096. 